\title{
ARTIKELEN
}

\section{Macht, misdaad en exces}

\section{Enkele inleidende reflecties}

Bas van Stokkom \& Marc Schuilenburg

Ons leven wordt sterk beheerst door het thema 'schaarste'. Of het nu gaat om onze veiligheid of gezondheid, we zijn voortdurend bang iets tekort te komen. In zijn boek Het rijk van de schaarste meent Hans Achterhuis (1988) dat schaarste ontstaat wanneer twee personen een bepaald goed willen hebben en het onmogelijk is om dat goed allebei tegelijk te bezitten. Dit uitgangspunt werd al verwoord door de zeventiende-eeuwse Britse filosoof Thomas Hobbes. In zijn werk Leviathan uit 1651 maakt Hobbes van schaarste zelfs de vooronderstelling van onze samenleving. Hij meent dat er een diepe kloof bestaat tussen enerzijds de behoeften van mensen en anderzijds de middelen waarover wij beschikken om onze behoeften te vervullen. Door dit tekort ontstaat een felle strijd tussen mensen, waarbij geweld niet wordt geschuwd om andermans goederen te verkrijgen of andere personen aan je te onderwerpen. Volgens Achterhuis loopt het vraagstuk van schaarste als een rode draad door het westerse denken en hij wijst in dit verband ook op het werk van denkers als Jean-Jacques Rousseau en Karl Marx.

In Het eeuwige tekort trekt Rutger Claassen (2004) de analyse van Achterhuis door en wijst erop dat de behoefte aan sociale erkenning leidt tot een gevoel van een permanent tekort. Schaarste geeft ons identiteit. Dit klinkt paradoxaal. Maar juist in de strijd om schaarse middelen als geld, liefde en respect veroveren we een positie in de samenleving. Voor wie ernaar zoekt, is het niet moeilijk voorbeelden hiervan te vinden. In een neoliberale samenleving worden we voortdurend aangemoedigd om in competitie met elkaar te treden en zo een identiteit te verwerven. De Franse schrijver Michel Houellebecq spreekt in dit verband van 'een wereld van markt en strijd'. Dat kan excessieve vormen aannemen. Zo heeft de Portugese voetballer Cristiano Ronaldo op Instagram meer dan 200 miljoen volgers. Hij verdient hiermee jaarlijks $€ 43$ miljoen en dat is meer dan bij zijn werkgever Juventus. Na het delen van een familiefoto kon hij alleen al op Instagram binnen een uur rekenen op meer dan een miljoen likes.

In de psychoanalyse wordt de behoefte aan sociale erkenning uitgelegd in termen van verlangen en tekort. Dit zorgt ervoor dat personen in actie komen. We verlangen namelijk altijd 'iets meer' of 'nog iets anders'. Het tekort is zo op te vatten als de drijfveer in ons leven. De Franse psychoanalyticus Jacques Lacan noemt dit een 'zijnstekort'. Dit betekent dat het tekort structureel is voor het bestaan van de mens, omdat de invulling ervan nooit echt lukt. Volgens Lacan leidt elk goed waarmee ons verlangen wordt bevredigd opnieuw tot een tekort vanwaaruit dit 
verlangen opnieuw ontstaat. Je zou ook kunnen zeggen dat ons leven in het teken staat van het hysterische adagium: 'Het is nooit genoeg' (Schuilenburg, 2019).

Om elk misverstand te voorkomen, het gevoel van tekort heeft de samenleving vooruitgeholpen in termen van veiligheid, gezondheid en welvaart. Maar de keerzijde ervan is dat het ook eigensoortige problemen met zich meebrengt. Een van die problemen is 'het exces'. Daarover gaat dit themanummer van het Tijdschrift over Cultuur en Criminaliteit. In de bijdragen aan dit nummer wordt niet alleen aangeknoopt bij studies van kritische en culturele criminologen over de structurele overexploitatie van het milieu en de opzichtige consumptiecultuur in de rapmuziek, maar is er ook aandacht voor gerationaliseerde vormen van verrijking in megaondernemingen en voor de uitwassen binnen de consumptiemaatschappij. Maar wat betekent 'exces' precies?

\section{Betekenissen van exces}

Slaan we het woordenboek erop na, dan wijst de van Dale op de volgende betekenissen van 'exces': buitensporigheid, een uitspatting of daad van geweld, en overschrijding van ambtsbevoegdheid. Exces duidt volgens de Oxford English Dictionary op extravagante inbreuken op de wet, fatsoen of moraal, buitensporig gedrag, maar ook op overschrijding van grenzen van gezagsuitoefening. Exces duidt dus wat abstracter geformuleerd op een teveel: meer dan wat nodig, verstandig of acceptabel is. In de klassieke oudheid werd dit 'teveel' gezien als schadelijk voor het uitoefenen van de deugden, bijvoorbeeld in Aristoteles' leer van het juiste midden. Antieke filosofen zagen de onverzadigbare honger naar 'meer' en het onbegrensde verlangen naar meer middelen als corrumperend in zichzelf. Volgens socioloog Emile Durkheim gaat dat gepaard met excessieve verlangens, 'the disease of the infinite' (1993: 287) (oorspronkelijk: 'le mal de l'infini'). Het menselijk verlangen is onverzadigbaar en inherent gevaarlijk, en behoeft daarom inperking door sociale normen. 'Our capacity of feeling is in itself an insatiable and bottomless abyss' (1993: 247), zo schrijft Durkheim.

In de moderne sociale wetenschappen is het exces relatief weinig bestudeerd, maar er lijkt een inhaalslag gaande. Volgens socioloog Andrew Abbott (2014) draait de centrale problematiek van de laatmoderniteit rondom het exces: het 'obsessieve teveel' vormt een drijvende kracht in ons bestaan en neemt veel van onze ambities in beslag. Hij paalt het begrip af van schaarste en overvloed en geeft de volgende beknopte omschrijvingen: 'schaarste' betekent te weinig van iets hebben, 'overvloed' betekent over meer dan genoeg beschikken, en 'exces' betekent een teveel van iets. Anders dan exces verwijst overvloed niet noodzakelijk naar een 'teveel', naar buitensporig of mateloos handelen. ${ }^{1}$ Daarentegen duidt exces juist wel op een ontsporing, een zich te buiten gaan aan iets: een uitwas of uitspatting. Het exces brengt dan ook eigensoortige problemen voort die geheel afwijken van schaarsteproblemen. Abbott onderscheidt 'too much', dat hij in ver-

1 Een 'anomie of affluence' (Simon \& Gagnon, 1976) kan moeilijk duidelijk maken hoe overvloed zou culmineren in corruptie of delinquent handelen (zie Van Stokkom, 2018). 
band brengt met verzadiging ('surfeit'), van 'too many', dat gerelateerd is aan wanordelijkheid ('welter'). Het eerste probleem kan resulteren in verlamming, verveling of verslaving. Het tweede probleem kan desoriëntatie en waarde-instabiliteit met zich meebrengen: geen houvast hebben en gebukt gaan onder te veel keuzemogelijkheden. Exces kan dus betrekking hebben op handelwijzen die alle grenzen overschrijden en daardoor onaanvaardbaar worden.

\section{Legaal of illegaal?}

Talloze vormen van excessief gedrag zijn volkomen legaal: het bacchanaal, de orgie, roes en dronkenschap. Niettemin kan dat gedrag grote publieke repercussies hebben, denk bijvoorbeeld aan het verkwisten van voorraden en het er doorheen jagen van fortuinen. De vernietiging van waarde ('verkwisten'/'vernielen') mag dan niet bij voorbaat crimineel zijn, wel zijn er raakvlakken met criminogeen handelen en het uit de weg gaan van verantwoordelijkheid. Daarentegen zijn excessieve handelwijzen waarin een element van 'overpowering' ligt vervat, zoals gewelddadig handelen maar ook plunderen en roven, verwant met strafbaar handelen. Zo geldt bijvoorbeeld kinderarbeid als exces van het ongebreidelde kapitalisme. $^{2}$

Over datgene wat onaanvaardbaar is, valt te twisten. Sommigen vinden prostitutie een exces, anderen een aangename vrijetijdsbesteding. Decadentie, verkwisting en aanstootgevende rijkdom roepen niet bij voorbaat afkeurende reacties op. Excessief gedrag is dus niet per definitie obsceen, pervers of immoreel. Al je bezittingen weggeven bijvoorbeeld of een langdurige vastenperiode ondergaan, kan op veel goedkeuring rekenen in de samenleving. Dat is anders in het geval van de onbezorgde manier van omgang met macht, rijkdom en het fortuin van de ultrarijken. Voor corrupte politici en grootondernemers lijkt de toe-eigening en exploitatie van publieke goederen een vanzelfsprekendheid. Momenteel vertonen veel Russische oligarchen en uiteraard ook Poetin kleptocratische kenmerken. ${ }^{3}$ Zo wordt het vermogen van Poetin door sommigen op $€ 56$ miljard geschat. Wanneer we op deze berichten stuiten, is onze eerste reactie dat hier iets niet klopt: het gaat om waanzinnige vermogens, verdwazing en extreme wanverhoudingen.

De term 'exces' kan ook op een uitzonderlijke situatie duiden. Een voorbeeld is de Excessennota (1969) van de Nederlandse regering over het gewelddadige optreden van Nederlandse militairen in Indonesië, waaronder de massamoord in Rawagede. Het vertoonde optreden was mateloos gewelddadig en een afwijking van wat verwacht mocht worden. Dat geldt ook voor 'excessief politieoptreden' waarvan de gewelddadige dood van George Floyd in Minneapolis in het voorjaar van

2 Zie www.woorden.org/woord/exces.

3 De Duitse afdeling van Transparency International publiceerde in 2004 een lijst met voormalige staatshoofden die het meeste geld uit de staatskas hebben geroofd: Muhammad Soeharto (Indonesië 1967-1998) US \$ 15 tot 35 miljard, Ferdinand Marcos (Filipijnen 1965-1986) 5 tot 10 miljard, Mobutu Sese Seko (Zaïre 1965-1997) 5 miljard, Sani Abacha (Nigeria 1993-1998) 1 miljard, Slobodan Milošević (Joegoslavië 1989-2000) 1 miljard, Jean-Claude 'Baby Doc' Duvalier (Haïti 1971-1986) 300 tot 800 miljoen (https://nl.wikipedia.org/wiki/Kleptocratie). 
2020 een tragisch voorbeeld is. Militair en politieel geweld is per definitie genormeerd en geregeld geweld. Hierdoor wordt het mogelijk aan te geven waar geweld in een geweldsexces omslaat (De Swaan, 2007: 215). Dat geldt ook voor straf: het opleggen van wrede en onmenselijke straffen wordt excessief genoemd.

Binnen de reguliere criminologie bestaat relatief weinig aandacht voor het vraagstuk van het exces en de culturele en sociale achtergronden ervan. In zekere zin is dat logisch, want veel excessieve praktijken - zoals het binnenhalen van absurde geldbedragen - zijn niet strafbaar. Volgens Vincenzo Ruggiero (2000) ontbreekt het de criminologie daarom aan conceptueel gereedschap om het exces te ontleden. De klassieke criminologie maakt van het vuil en de goot het belangrijkste terrein van onderzoek. Steeds draait het om armoede, achterstelling, gebrek en de nood van kwetsbaren. We dienen volgens hem van dat deprivatieperspectief - het verstoken zijn van kansen, hulpbronnen en fatsoenlijke socialisatie - over te stappen naar een perspectief op onwettige praktijken die in het teken staan van overvloed, rijkdom en exces. 'Relatieve deprivatie' zou daarmee plaatsmaken voor 'relatieve overvloed' (Ruggiero, 2000: 8).

\section{Batailles visie op exces}

Om het thema 'exces' meer duiding te geven, hebben sociologen en criminologen zich laten inspireren door het werk de Franse schrijver en filosoof Georges Bataille. Deze theoreticus van het exces staat samen met filosofen als Friedrich Nietzsche en George Sorel te boek als een 'gevaarlijk denker' die veel aandacht schonk aan de irrationele, libidineuze en orgiastische aspecten van menselijk handelen.

Bataille vat exces op als surplus-energie die overblijft nadat (re)productieve activiteiten zijn verricht en noodzakelijke behoeften zijn vervuld. Wanneer die energie niet kan worden geabsorbeerd in de groei van het maatschappelijk organisme, moet dat teveel worden geloosd: 'It must be spent, willingly or not, gloriously or catastrophically' (Bataille, 1985: 21). Hij spreekt in dit verband over een onproductieve 'algemene economie van exces', welke onder meer verspilling, vernietiging, verlies en afval met zich meebrengt. Dat nutteloze verbruik is volgens Bataille de primaire determinant van iedere cultuur. De volgende heterogene activiteiten kunnen begrepen worden als verspilling van een surplus aan energie: luxe, oorlog, rouw, grootse monumenten, wedstrijden, spektakel, kunsten, perverse seks - allemaal activiteiten die buiten zichzelf geen doel hebben.

Bataille kritiseert de moderne, op nut afgestemde samenleving waarin dergelijke ontladingen in mindere mate zouden kunnen plaatsvinden. Rituele en extatische activiteiten worden onbegrijpelijk en de 'algemene economie van exces' die kenmerkend was voor het sociale leven in voormoderne tijden, werd aldus naar de marge van de samenleving verdrongen. Maar het is volgens Bataille de vraag of de moderne op nut en rationaliteit gebaseerde 'beperkte economie' in staat is alle surplus-energie te kanaliseren. Weliswaar kent deze economie zijn eigen verspillingsrituelen die gerelateerd zijn aan de verwerving van status, maar de bourgeoisie - anders dan de adel en het gewone volk - houdt verkwisting voortaan uit het 
publieke zicht, in overeenstemming met haar 'deprimerende conventies' en 'vernederende concepties van ingeperkt verteren' (1985: 124).

Batailles hypothese van de marginalisering van exces was aannemelijk in een kapitalistisch systeem dat de nadruk legde op spaarzaamheid en uitstel van behoeftebevrediging. In de huidige, laatmoderne vormen van kapitalisme lijken de veelvoudige uitdrukkingsvormen van exces die Bataille schetste, wederom veel aantrekkingskracht te hebben. Bataille was niet in staat om zich een kapitalisme voor de geest te halen dat de aandrang tot exces en het vieren van energie economisch zou accommoderen en exploiteren. Evenmin voorzag hij dat de commerciële exploitatie van extatische ervaringen en wilde excessen het recuperatieve vermogen van het kapitalisme zou kunnen bevorderen (zie daarvoor: Boothroyd, 2006; Botting \& Wilson, 1997).

Sommige sociologen en criminologen hebben voortgebouwd op Batailles analyse van excessieve rituelen. Zo heeft Mike Presdee (2000) studie gemaakt van de vitale hartstochten en subversieve opwinding van het 'carnaval van misdaad'. Presdee veronderstelt - conform Bataille - dat dit carnaval cultureel noodzakelijk is, maar tegelijk - anders dan Bataille - dat de behoefte aan opwinding en het opzoeken van grensoverschrijdend gedrag een grote vlucht heeft genomen. Hij schrijft dat onder meer toe aan de 'ondraaglijke rationaliteit' van het moderne leven, waardoor carnavaleske rituelen een dagelijkse noodzaak zijn geworden om te kunnen overleven. Tegelijk merkt hij op dat deze vormen van extatisch en subversief plezier vercommercialiseerd zijn en opgenomen in het vermaaksaanbod. Zo zijn opwindende ervaringen rondom SM en blind dates losgemaakt van de originele functies van carnaval en opgenomen in een grote variëteit van entertainmentproducten.

Een van de excessieve rituelen die onder bereik is gekomen van de grote massa is het kooigevecht. Mixed martial arts (MMA)-toernooien laten zien dat de behoefte om vleselijk geweld te aanschouwen - het tot bloedens toe kapot slaan van hoofd en lijf - nog altijd levendig is en onder een opgezweept massapubliek veel geestdrift losmaakt. Volgens Jennifer Jane Hardes (2019) vormt dat een bevestiging dat er sterke rituele verlangens zijn die de biopolitieke bescherming en regulering van het leven te boven te gaan. De groei van de MMA-business toont volgens haar aan dat een groot publiek reikhalzend uitkijkt naar evenementen waar de behoefte aan afrossen en kastijden uitgeleefd kan worden.

Anderen suggereren dat de eertijds verborgen en verbannen punitieve surplusenergieën sinds enkele decennia weer in het volle licht van de publieke schijnwerpers zijn komen te staan. Zo werpt Sarah Wright de these op dat in de context van schandalen en ernstige incidenten de reservoirs van surplus-energie snel overlopen. Die krachtbronnen stuwen tot morele paniek, een 'geheel van begeerten die tezamen een explosieve ontlading van surplus-energieën teweeg brengen' (Wright, 2010: 191). Morele paniek kan aldus als manifestatie van een 'economie van exces' worden beschouwd. In een studie over de punitieve wending die sinds de jaren 1980 ingang heeft gevonden, zet Simon Hallsworth (2000) uiteen dat hedendaagse strafverlangens in de context geplaatst kunnen worden van wat Bataille een 'algemene economie van exces' noemde. De strafpraktijken in Angelsaksische landen beantwoorden weer aan de punitieve passies van uitzinnige 
menigten. De punitieve wending moet volgens Hallsworth begrepen worden als ondermijning van het moderne, ingetoomde strafrechtelijke systeem, inclusief de humanistische discoursen van de Verlichting.

\section{Extravagante misdaad en excessieve veiligheidsverlangens}

Een van de weinige criminologen die uitgebreid heeft geprobeerd het concept 'exces' toe te passen op de sociale analyse van misdaad en veiligheid is Ian Loader (2009). In zijn studie Ice cream and Incarceration wijst hij erop dat veel criminologen extravagante vormen van misdaad steevast toedichten aan gemarginaliseerde groepen die niet in staat zijn hun impulsen en verlangens te beheersen. Zo menen Michael Gottfredson en Travis Hirschi (1990: 15) in A General Theory of Crime dat alle misdaad voortkomt uit egoïstische impulsen, het verlangen naar onmiddellijke bevrediging en afwezigheid van reflectie op toekomstige gevolgen. Personen die risico opzoeken en impulsief, ongevoelig, kortzichtig en non-verbaal zijn aangelegd, zijn vatbaarder voor crimineel handelen. Misdaad hangt zo samen met gedrag als roken, drinken, drugsgebruik, gokken, slechte opvoeding en kinderen die voortspruiten uit buitenhuwelijkse, vlugge seks. Het gaat dus om mensen die nooit geleerd hebben hun gedrag te beheersen en een slechte socialisering achter de rug hebben.

Loader beaamt dat misdaad vaak voortkomt uit een 'pleasure-producing act' en het negeren van belangen van anderen. Maar er doet zich een probleem voor: waarom niet de pleziertjes, uitspattingen en gebrek aan zelfcontrole noemen van mensen uit de midden- en hogere lagen? Excessief handelen en zich te buiten gaan lijken een breed probleem van zelfbeheersing te openbaren dat zich in alle lagen van de bevolking voordoet. Het argument van gebrekkige socialisering klopt dan ook niet, of je moet veronderstellen dat nette jongens en meisjes uit de middenklassen die veel de wereld over vliegen, pillen slikken en over uitpuilende garderobes beschikken, in hun jeugdjaren verwaarloosd zijn. Om die reden concludeert Loader dat de theorie van Gottfredson en Hirschi eenzijdig is en uitmondt in een ideologische cul-de-sac (2009: 245).

Het is jammer dat Loader niet is ingegaan op de aanname dat buitensporig gedrag juist kenmerkend is voor de (ultra)rijke klassen. Zo blijkt uit een studie over 'elitist stancemaking' dat exces, genot en onmatigheid positieve betekenissen hebben in vermogende milieus (Jaworski \& Thurlow, 2009). In het befaamde boek The Leisure class - de vertaalde editie heet De theorie van de nietsdoende klasse - had socioloog Thorstein Veblen al eerder de pronk- en spilzucht van Amerikaanse elites rondom 1900 op de hak genomen - de bombast van hun paleizen, decadente trofeevrouwen, snobistische jachtrituelen en andere vormen van aanstootgevend handelen (Veblen, 2017). ${ }^{4}$

Loader betoogt verder dat de hedendaagse obsessie met securitisering, inclusief de fantasie dat alle misdaadrisico's geëlimineerd kunnen worden, wordt geken-

4 Uit recenter Amerikaans onderzoek blijkt dat mensen die over een hoog inkomen beschikken, egocentrischer zijn en zich aanmatigender gedragen dan mensen die over weinig middelen beschikken (Krauss et al., 2012; Piff et al., 2012). 
merkt door rusteloosheid, ongeduld, ongenoegen en oververhitte emoties. Het tamboereren op steeds meer veiligheid kan dan ook begrepen worden als een excessief verlangen dat voortkomt uit de drang naar ogenblikkelijke bevrediging, zonder rekening te houden met de toekomstige impact van je handelen. Dat zijn overigens precies de drijfveren die volgens Gottfredson en Hirschi ten grondslag liggen aan misdaad. Veiligheidsverlangens moeten ogenblikkelijk bevredigd worden, inclusief het pleidooi voor harde straffen en hoge hekken om het land. Volgens Loader openbaren die verlangens een weigering om beperkingen te accepteren, terwijl voorzichtigheid, twijfel, zelfcontrole en matiging als hindernissen worden ervaren.

Hij plaatst die ontwikkeling tegen de achtergrond van de onstuimige groei van overvloed sinds de jaren 1950. Welvarende samenlevingen produceren een eindeloze hoeveelheid nieuwe goederen en diensten, waaronder veiligheidsproducten, waardoor prudentie, feilbaarheid en commitment aan de samenleving zijn gemarginaliseerd. Het resultaat is een 'self-regarding individualism' en de zegetocht van een door impulsen gevoede 'myopic choice'. Het culturele overwicht van 'bijziend kiezen', vervolgt Loader, zou het hedendaagse excessieve strafbeleid wel eens kunnen verklaren. Repressieve antwoorden op incidenten, aanslagen en schandalen zijn slecht doordacht en worden overhaast genomen, kenmerkend voor een samenleving waarin mensen 'security now' opeisen en ogenblikkelijk aanslaan wanneer zij denken te worden gehinderd. In die context spreekt Loader over veiligheidshonger en egocentrische voorkeuren die het hart vormen van een verspillende consumptiecultuur.

\section{Hybris: exaltatie en machtsverdwazing}

Excessief handelen staat vaak in het teken van de verlokking grenzen af te tasten en die te overschrijden. In dit verband is de theorie van edgework interessant, het opzoeken van grenzen van wat nog mogelijk of te dragen is (Lyng, 1990; zie ook Cohen \& Taylor, 1992). Edgework duidt op vrijwillig risico nemen en participeren in gevaarlijke activiteiten die controlevaardigheden vereisen. Anders dan bij gokken en sensatie zoeken het geval is, zijn competentie en 'mentale hardheid' vereist, in termen van controle houden over chaotische situaties. Het gaat om het aangaan van uitdagingen, niet om het je overgeven aan het lot. Edgework kan zowel kickervaringen als almachtgevoelens met zich meebrengen (Lyng, 1990: 860). ${ }^{5}$ Veel psychologen en psychoanalytici wijzen in dat verband op euforie en exaltatie, toestanden van koortsige opwinding, vervoering en dronkenschap, bijvoorbeeld in de sport en in seks- en gokhuizen, maar ook in kunst, politiek en religie. In de wetenschap kennen we de intellectuele exaltatie: het waanbeeld ver uit te steken boven het modale weten. Studies van handelaren van financiële pro-

5 Lyng (1990) ziet edgework als verzet en een ontsnapping aan vervreemdende arbeidsomstandigheden en het benauwde rationalisme van de risicosamenleving. Interessanter is wellicht om edgework te verbinden met het werk en vrijetijdsbesteding van vrijzinnigen, vaak in geprivilegieerde milieus, die worden aangemoedigd uitdagingen aan te gaan en zich te bewijzen (zie hiervoor Mascini et al., 2015). 
ducten laten zien dat dergelijke waanbeelden een repeterend patroon kunnen verkrijgen en vaak gepaard gaan met verslaving (Coates, 2012; Wexler, 2010).

In de context van machtsuitoefening zijn overmoed en hoogmoed interessante categorieën, vooral wanneer (potentieel) machtigen hun aspiraties niet onder controle hebben en veel schade kunnen aanrichten. Mogelijk nemen dan impulsen en verlangens het roer over, inclusief fantasieën rondom die verlangens. Buitensporige verlangens van bestuurders en topmanagers kunnen connotaties hebben met machtsverdwazing, in termen van roekeloosheid en het opzoeken van onverantwoorde risico's (Van Stokkom, 2018).

Excessieve ambities, grootheidswaan en machtsverdwazing zijn vanouds - vooral door historici en psychologen - tot onderwerp van studie gemaakt, vaak vertrekkend vanuit de klassieke notie van 'hybris'. Zo is uitgebreid studie gemaakt van de megalomane denkwereld van Napoleon, Hitler en andere manische en getourmenteerde politieke leiders. De emotiesocioloog Thomas Scheff heeft daarbij de achterliggende maatschappelijke factoren in kaart gebracht, in het bijzonder rancune, revanchisme en 'verdrongen schaamte' (Scheff, 1994). Economen en sociaalpsychologen hebben recentelijk veel studie gemaakt van hebzucht en grootheidswaan onder bestuurders van grote beursgenoteerde ondernemingen. ${ }^{6}$

In de Griekse oudheid had hybris betrekking op mensen die de door goden bepaalde grenzen van menselijk gedrag trotseerden en vervolgens de woede van de wraakgodinnen over zich afriepen, denk aan de roekeloze Icarus. De moderne betekenis van hybris komt tot uitdrukking in het Bijbelse gezegde "hoogmoed komt voor de val'. Hybris duidt op verdwazing en verblinding, gekenmerkt door arrogantie, trots, overmoed en een gevoel van almacht. Tegenwoordig wordt hybris als een persoonlijkheidskenmerk gezien en is daarom vooral door sociaalpsychologen onderzocht. Zij wijzen onder meer op realiteitsverlies, een overschatting van eigen competenties en vermogens, en narcistische zelfbewieroking. Neuroloog en voormalig Labour-politicus David Owen schetst de omgang tussen George Bush en Tony Blair ten tijde van de oorlog in Irak als 'folie à deux', waarbij zij elkaars illusies en waandenkbeelden wisten te versterken. Blair was messianistisch geworden, had een onwankelbaar gevoel van zekerheid en een verminderd vermogen tot zelfonderzoek (Owen, 2012: 182-183).

In een beschouwing over de verleiding van macht zet de psycholoog Jaap van Ginneken (2013) uiteen dat politieke leiders vaak op dwangmatige wijze risico's nemen en voortdurend op zoek zijn naar prikkels. Ze zijn overtuigd van hun unieke capaciteiten, negeren waarschuwingssignalen en zijn tot op zekere hoogte paranoïde. Steevast worden daarbij kwalijke eigenschappen op politieke tegenstanders geprojecteerd, zo stelt Van Ginneken (2013: 132). De taal van politieke topleiders verraadt een grote machtsbehoefte en een opgeblazen geloof dat zij wereldgebeurtenissen kunnen controleren. Volgens Van Ginneken activeert macht niet alleen egocentrisme, maar ook geilheid en seks. Hij spreekt in dit ver-

6 Volgens Cools (2005) was de ondergang van beursgenoteerde ondernemingen na de boekhoudschandalen die zich rond 2000-2002 voordeden, te wijten aan drie factoren: onrealistische targets voor winst- en omzetgroei (luchtkastelen), exorbitant hoge persoonlijke bonussen (hebzucht) en het marginaliseren van interne controle (zonnekoning-gedrag). 
band over een winnaarseffect: politieke leiders zijn dol op trofeevrouwen en menen dat buitenechtelijke verhoudingen bij hun status horen. Ontsporingen worden doorgaans strikt geheimgehouden, maar het geval Berlusconi leert dat vreemdgaan, perversie en buitenechtelijke kinderen kunnen bijdragen aan het charisma van de leider (2013: 53).

De studies van Owen en Van Ginneken tonen overtuigend aan dat bijna alle politieke leiders - ook de 'burgerlijke' typen onder hen zoals Kohl en Hollande gebukt gaan onder hybris en dat de deur voor corruptie en machtsbederf daardoor wagenwijd openstaat. ${ }^{7}$ Overigens hebben onderzoekers regelmatig overmoed en acquisitiewaanbeelden vastgesteld bij CEO's van grote bedrijven. ${ }^{8}$ Overmatig geloof in toekomstige prestaties en successen en overmatige zelfverzekerdheid zetten bestuurders ertoe aan de bedrijfsmissie koste wat kost te behalen (Van Stokkom, 2018). Sommige criminologen hebben deze problematiek van overmoed onderzocht. Piquero en collega's wijten die problematiek aan de illusie dat alle ambities onder controle te houden zijn. Vaak menen CEO's dat zij aan de touwtjes trekken en dat succes aan hun eigen verrichtingen te danken is. Deze 'illusie van controle' wordt wel gedefinieerd als een inflatoire verwachting van persoonlijk succes. Volgens de onderzoekers gaat dat gepaard met 'delusions of grandeur and poor judgment in business decisions' (Piquero et al., 2005: 260).

\section{De cultuur van geprivilegieerden}

De vraag is of sociaalpsychologische benaderingen van hoog- en overmoed wel altijd overtuigen. Het onbezonnen gedrag van bestuurders heeft niet altijd te maken met persoonlijke eigenschappen. Het geloof dat hoge ambities te verwezenlijken zijn en dat altijd controle kan worden behouden, reflecteert wellicht eerder bepaalde sociale normen die in specifieke leeromgevingen, vaak subculturen van geprivilegieerden, eigen worden gemaakt.

Neil Shover heeft in een interessante overzichtsstudie aangetoond dat de levenswijzen van geprivilegieerden als 'generatieve werelden' van misdaad fungeren (Shover, 2007). Een aanzienlijk deel van de witteboordencriminelen komt volgens Shover uit een ondernemersmilieu met een zorgeloos leven, vrij van geldproblemen of de strijd tegen een faillissement. Het gaat om een beschermde omgeving waarin jongvolwassenen veel speelruimte wordt gegund en veel kansen en gelegenheden beschikbaar zijn. Zij maken zich cultureel kapitaal eigen dat een uitgebreid en ingenieus scala van neutraliseringen bevat om de mogelijke schadelijkheid van hun activiteiten te ontzenuwen.

7 Sociaalpsychologisch onderzoek wijst erop dat machtsposities twee belangrijke psychische transformaties teweeg kunnen brengen: gedragsontremming en een verhoogde zelfgeoriënteerde focus. Machtige personen willen minder hindernissen en risico's waarnemen. Zij zijn er bedreven in hun verlangens van geschikte rationalisaties te voorzien, of het nu gaat om vreemdgaan of riskante bedrijfsovernames (zie Lammers \& Van Beest, 2014).

8 Voor onderzoek naar hybris in de bestuurskamers van grote ondernemingen zie Wray (2016) en Sadler-Smith (2016). 
Volgens Shover springen er in de attitudes van geprivilegieerden drie aspecten uit die misdaad kunnen faciliteren: de drang om rivalen de loef af te steken, een diepgaand gevoel van arrogantie en een ethos van aanmatiging ('entitlement'). Wat rivaliteit betreft: interviews met veroordeelde witteboordencriminelen maken duidelijk dat zij zich identificeren met de hiervoor genoemde onbeteugelde wereld van markt en strijd. Shover brengt dat in verband met het verlangen respect af te dwingen door te winnen of uitzonderlijke prestaties neer te zetten. Arrogantie wordt onder meer gekenmerkt door de overtuiging dat wetten en regels niet voor jezelf gelden. Het derde aspect, het ethos van aanmatiging, heeft betrekking op het geloof dat je overal aanspraak op kunt maken. Dat houdt verband met de overtuiging dat de geleverde inspanningen en prestaties heel bijzonder zijn en dat de samenleving daarvan profiteert. Mede daarom worden tegenvallende inkomsten als oneerlijk gezien en wordt fel weerstand geboden aan belasting betalen en verwante belemmeringen (Shover, 2007: 92).

Geprivilegieerden houden er dus specifieke opvattingen op na om hun statusposities te legitimeren. ${ }^{9}$ Een tweede reden waarom een focus op hybris en persoonlijkheidskenmerken niet volstaat, houdt verband met de machtsstructuren binnen grote organisaties en bedrijven, en met de specifieke branche- en organisatiecultuur. Zo zijn topbestuurders en topmanagers in staat wetsontduiking en -overtreding te laten arrangeren en het falen van die strategieën op medewerkers lager in de hiërarchie af te schuiven. Zij zijn vaak ook in staat controle en toezicht op hun bedrijven lam te leggen. Dat kan in navolging van C.W. Mills als 'georganiseerde onverantwoordelijkheid' worden geduid (Curran, 2018).

Charles Tittles categorie van 'controle surplus' is hier ook interessant, omdat die betrekking heeft op een gevrijwaard zijn van controle en een zekere onaantastbaarheid. Volgens Tittle (2018) neigen mensen die over een 'controle surplus' beschikken, ertoe om kritiek op en verzet tegen hun leiding af te doen als ongehoorzaamheid of ondankbaarheid. Het gedrag van patriarchen, bijvoorbeeld gezinshoofden die 'minderen' tuchtigen, is daarvoor illustratief. Motieven die daarbij een rol kunnen spelen, zijn hebzucht (accumulatie van bezit), statusbehoud en de lust te domineren. Volgens Tittle gaat 'controle surplus' gepaard met uiteenlopende vormen van deviant gedrag, waaronder exploitatie (bijvoorbeeld onderbetaling, omkoping en prijsafspraken), plundering en decadentie.

\section{Normalisering van exces?}

In het Amerikaanse aandeelhouderskapitalisme dat vanaf 1980 - toen onder de neoliberale Ronald Reagan en Margaret Thatcher omwentelingen plaatsvonden aan een wereldwijde opmars bezig is, geldt maximalisering van winst onomwonden als primair doeleind van ondernemen. Er bestaat dan ook grote druk om hoge winsten te realiseren of het marktaandeel koste wat kost uit te breiden. Dat heeft er feitelijk toe geleid dat disproportioneel veel geld en vermogen in handen is

9 Er zijn intussen veel cultuursociologische studies beschikbaar over de manieren waarop geprivilegieerde groepen hun statusposities legitimeren; zie o.a. Davis, 2017; Harrington, 2016; Kantola \& Kuusela, 2019. 
gekomen van een kleine mondiale toplaag van ultrarijken (Piketty, 2014). Maar een neoliberale economie spoort ook gewone burgers aan zichzelf te verrijken. Sommigen spreken in dat verband over de normalisering van de hebzucht (Linssen, 2019). Wellicht komt de normalisering van exces nog markanter tot uitdrukking in de entertainmentindustrie.

Mediaconsumenten worden dagelijks bedolven onder een stortvloed van spektakel, opwinding en reclame, waarbij verspillen en verbrassen als vanzelfsprekend worden voorgesteld. Tegen die achtergrond bezien stelt socioloog Zygmunt Bauman dat de consumptiemaatschappij bij elkaar wordt gehouden door verleiding, verlokking en het opwekken van nieuwe verlangens waarmee de droom van geluk levend kan worden gehouden. Dat betekent dat exces, 'de gezworen vijand van de norm', zelf de norm is geworden. 'Excess means right measure and wastefulness means being creative and productive' (Bauman, 2001: 91).

Deze fantasierijke assumptie impliceert dat excessief brassen of verkwisten voortaan minder weerstand zou oproepen. Dat is niet plausibel. Excessieve pronk- en spilzucht blijft veel protesten losmaken. De kritiek op hebzucht en zelfverrijking die al eeuwenlang op het kapitalisme wordt uitgeoefend, is bepaald niet verstomd, de spectaculaire opkomst van een volks neoliberaal zelfbeeld ten spijt (Linssen, 2019; Hancock, 2017; Cushman, 2015). De levenswijzen van de ultrarijken worden nog altijd geassocieerd met decadentie en bederf. Exorbitante rijkdommen lijken na de crisis van 2008 met meer geestdrift te worden gehekeld, niet in de laatste plaats door veel ultrarijken zelf (Riad, 2014).

Wanneer excessief handelen betrekking heeft op beschadigen en vernietigen, de uitroeiing van diersoorten, het kappen van wouden en het lozen van giftig afval, lijkt die kritiek nog pregnanter door te klinken. In 2019 becijferde VN-natuurorganisatie IPBES dat $75 \%$ van de aardoppervlakte en $66 \%$ van de oceanen ernstig is aangetast door menselijk handelen. De gevolgen hiervan zijn immens. Zo worden ongeveer een miljoen van de naar schatting acht miljoen plant- en diersoorten op aarde met uitsterven bedreigd en dat kan in veel gevallen al binnen enkele jaren tot een paar decennia gebeuren. Daarom gaan steeds meer stemmen op om 'ecocide' internationaal strafbaar te stellen, zodat bedrijven en landen die het milieu ernstige schade toebrengen, kunnen worden vervolgd (Higgins, 2010). Denk aan grote olielekken, leegvissen van de zee en ontbossing van grote delen van de wereld. Het exces staat dus onverminderd onder verdenking.

\section{In dit nummer}

De negatieve beoordelingen van excessieve handelwijzen sluiten aan bij de manier waarop de kritische criminologie te werk gaat: de schadelijke impact van machtsconcentraties, structurele ongelijkheid en rücksichtsloze exploitatie worden in die discipline aan nader onderzoek onderworpen. Cultureel criminologen daarentegen gaan doorgaans anders te werk. Zij vestigen onder andere de aandacht op (bizarre) sociale rituelen, (het plezier van) normoverschrijding en (collectieve) gevoelens van exaltatie. Denk aan studies van kooigevechten, illegaal gokken, groepsseks en bingedrinken. De oriëntaties van culturele en kritische criminolo- 
gen - en hun kennisbelang - kunnen dus behoorlijk uiteenlopen en dat is deels terug te zien in de bijdragen aan dit themanummer. Daarbij moet meteen worden aangetekend dat de meeste bijdragen bepaald niet verwant zijn met deze twee criminologische stromingen. De meeste auteurs hebben de problematiek van exces vanuit hun eigen vakdiscipline benaderd en dat varieert van filosofie, sociologie, accountancy tot cultuurgeschiedenis. Thematisch gezien focust dit nummer zo op excessen rondom cultureel sterk uiteenlopende sociale handelwijzen en de criminogene aspecten ervan. Dat kan variëren van verslaving, overmatige consumptie, inhaligheid tot overexploitatie van de natuur.

In het eerste artikel laten Robbert Goverts en Robert Roks zien hoe 'conspicuous consumption' tot uiting komt in Nederlandstalige rap en hoe de muzikanten in hun muzikale repertoire betekenis geven aan deze opzichtige uitgavenpatronen. In tegenstelling tot emulatie van de consumptiepatronen van de elite om sociale status te verkrijgen, laten de auteurs zien dat rappers luxegoederen combineren met duidelijke elementen uit de straatcultuur - zoals de nabijheid van criminaliteit en specifieke straattaal - en dat hierbij een bepaalde 'ghetto aestethic' behouden blijft.

In het tweede artikel gaat Daan van Uhm in op de criminogene impact van natuurexploitatie, waarbij antropogene defaunatie, ecologische interactie en risico's van zoönosen uitgebreid aan bod komen. Van Uhm stelt dat overexploitatie van de natuur een steeds zichtbaardere invloed heeft op sociaaleconomische, politieke en ecologische aspecten in onze samenleving en daarmee belangrijke criminologische vragen oproept.

Vervolgens wordt in drie essays uitgebreid ingegaan op andere aspecten van excessief handelen. Filosoof Jeroen Linssen biedt in zijn essay een historisch overzicht van het denken over hebzucht. Hij stelt - aansluitend op Bauman - dat in onze maatschappij begerigheid niet langer als exces wordt gezien, maar juist als een 'normale' economische stimulans. In een sociologische en historische beschouwing laat Stephen Snelders zien dat drugsgebruik van aanvang af gelabeld werd als excessief en dat de bestrijding ervan de ambivalentie tussen vrije consumptie en disciplinering van gedrag blootlegt. In het derde en laatste essay gaat Lucas de Melo Melgaço in op seksueel getinte graffiti in de metropool Brussel. Hij stelt de vraag van wie de openbare ruimte is en hoe daarin kan worden omgegaan met aanstootgevende kunst.

In de rubriek Discussie zijn twee stukken opgenomen. Marcel Pheijffer gaat in op het verschijnsel van excessieve beloningen binnen het aandeelhouderskapitalisme. Hij zet uiteen dat die beloningen risicovol handelen van managers en frauduleus boekhouden aanmoedigen. In het tweede discussiestuk pleit Hans Dagevos voor een kritische reflectie op de door ons zelfgecreëerde systeemstructuren die het consumentisme en onze afhankelijkheid daarvan in stand houden.

In de rubriek Doka - tot slot - is een foto opgenomen van muurposters in Hongkong die een indruk geven van het excessieve geweld van de politie. 


\section{Literatuur}

Abbott, A. (2014), The Problem of Excess. Sociological Theory, 32(1), 1-16.

Achterhuis, H. (1988), Het rijk van de schaarste: van Thomas Hobbes tot Michel Foucault. Ambo: Baarn.

Bataille, G. (1985), Visions of Excess. Selected Writings. 1927-1939. Minneapolis: University of Minnesota Press.

Bauman, Z. (2001), Excess: An Obituary. Parallax, 7(1), 85-91.

Boothroyd, D. (2006), Cultural Studies and the Extreme. In: G. Hall \& C. Birchall (eds.), New Cultural Studies: Adventures in theory (pp. 274-290). Edinburgh: Edinburgh University Press.

Botting, F. \& S. Wilson (1997), Introduction: From Experience to Economy. In: F. Botting \& S. Wilson (eds.), The Bataille Reader. Oxford: Blackwell.

Claassen, R. (2004), Het eeuwige tekort. Een filosofie van de schaarste. Ambo: Amsterdam.

Coates, J. (2012), The Hour between Dog and Wolf: Risk Taking, Gut Feelings, and the Biology of Boom and Bust. London: Fourth Estate.

Cohen, S. \& L. Taylor (1992), Escape Attempts: The Theory and Practice of Resistance to Everyday Life. London: Routledge.

Cools, K. (2005), Controle is goed, vertrouwen nog beter. Over bestuurders en corporate governance. Assen: Van Gorcum.

Curran, D. (2018), Organized irresponsibility. In: S. Bittle, L. Snider, S. Tombs \& D. Whyte (eds.), Revisiting Crimes of the Powerful: Marxism, Crime and Deviance. Abingdon: Routledge.

Cushman, T. (2015), The Moral Economy of the Great Recession. Society, 52, 9-18. doi: 10.1007/s12115-014-9852-4.

Davis, A. (2017), Sustaining corporate class consciousness across the new liquid managerial elite in Britain. The British Journal of Sociology, 68(2), 234-253.

Durkheim, E. (1993), Suicide. A Study in Sociology. London: Routledge (oorspronkelijke Franse uitgave 1899).

Ginneken, J. van (2013), Verleidingen aan de top. De psychologie van de macht. Amsterdam/ Antwerpen: Business Contact.

Gottfredson, M. \& T. Hirschi (1990), A general theory of crime. Stanford, CA: Stanford University Press.

Hallsworth, S. (2000), Rethinking the punitive turn: Economies of excess and the criminology of the other. Punishment and Society, 2(2), 145-160.

Hancock, D. (2017), Revulsion and awe: charting the development of the moral economy of capitalism and its hero in the American imagination, from the protestant ethic to ecstasy of the entrepreneur. Journal of Cultural Economy, 10(2), 136-149.

Hardes, J.J. (2019), Governing excess: Boxing, biopolitics and the body. Theoretical Criminology. doi: 10.1177/1362480619864310.

Harrington, B. (2016), Capital without Borders: Wealth Managers and the One Percent. Cambridge MA: Cambridge University Press.

Higgins, P. (2010), Eradicating ecocide: Laws and governance to prevent the destruction of our planet. London: Shepheard Walwyn Publishers Ltd.

Jaworski, A. \& C. Thurlow (2009), Taking an Elitist Stance: Ideology and the Discursive Production of Social Distinction. In: A. Jaffe (ed.), Perspectives on Stance (pp. 195-226). New York: Oxford University Press.

Kantola, A. \& H. Kuusela (2019), Wealth Elite Moralities: Wealthy Entrepreneurs' Moral Boundaries. Sociology, 53(2), 368-384. 
Krauss, M.W. et al. (2012), Social class, solipsism, and contextualism: How the rich are different from the poor. Psychological Review, 119(3), 546-572.

Lammers, J. \& I. van Beest (2014), The effects of power on immorality. In: J-W. van Prooijen \& P.A.M. van Lange (eds.), Power, politics, and paranoia: Why people are suspicious about their leaders (pp. 17-32). Cambridge University Press.

Linssen, J. (2019), Hebzucht. Een filosofische geschiedenis van de inhaligheid. Nijmegen: Vantilt.

Loader, L. (2009), Ice cream and incarceration: On appetites for security and punishment. Punishment and Society, 11(2), 241-257.

Lyng (1990), Edgework: A social psychological analysis of voluntary risk taking. American Journal of Sociology, 95(4), 851-886.

Mascini et al. (2015), Voluntary Risk Seeking in the Risk Society: Explaining Involvement in Edgework, Paper to be presented at the conference Risk and Uncertainty, University of Stuttgart, April 6-8, https://repub.eur.nl/pub/78005.

Owen, D. (2012), The Hubris Syndrome - Bush, Blair, and the Intoxication of Power. York: Methuen.

Piff, P.K., D.M. Stancato, S. Côté, R. Mendoza-Denton \& D. Keltner (2012), Higher social class predicts increased unethical behavior. Proceedings of the National Academy of Sciences, 109(11), 4086-4091.

Piketty, T. (2014), Capital in the Twenty-First Century . London: Harvard University Press.

Piquero, N.L., M.L. Exum \& S.S. Simpson (2005), Integrating the desire for control and rational choice in a corporate crime context. Justice Quarterly, 22, 252-280.

Presdee, M. (2000), Cultural Criminology and the Carnival of Crime. London: Routledge.

Rehn, A. \& D. O'Dohorty (2007), Organization: On the theory and Practice of Excess. Culture and Organization, 13(2), 99-113.

Riad, S. (2014), Leadership in the fluid moral economy of conspicuous consumption. Insights from the moralizing tales of Cleopatra and Antony. Journal of Management History, 20(1), 5-43.

Ruggiero, V. (2000), Crime and Markets. Essays in Anti-criminology. Oxford: Oxford University Press.

Sadler-Smith, E. (2016), Hubris in Business and Management Research: A 30-year Review of Studies. In: P. Garrard \& G. Robinson (eds.), The Intoxication of Power: Interdisciplinary Insights (pp. 39-74). Houndmills: Palgrave Macmillan.

Scheff, T. (1994), Bloody Revenge: Emotions, Nationalism and War. Boulder: Westview Press.

Schuilenburg, M. (2019), Hysterie. Een cultuurdiagnose. Amsterdam: Boom Filosofie.

Shover, N. (2007), Generative worlds of white-collar crime. In: H.N. Pontell \& G. Geis (eds.), International Handbook of White-Collar and Corporate Crime (pp. 81-97). New York: Springer.

Simon, W. \& J.H. Gagnon (1976), The Anomie of Affluence: A Post-Mertonian Conception. American Journal of Sociology, 82(2), 356-378.

Stokkom, B. van (2018), De anomie van machtsillusies. Onbegrensde ambities in de 'risk and win'-zakenwereld. Tijdschrift over Cultuur en Criminaliteit, 8(1), 54-77.

Swaan, A. de (2007), Bakens in niemandland. Opstellen over massaal geweld. Amsterdam: Bert Bakker.

Tittle, C.R. (2018), Control Balance: Toward a General Theory of Deviance. Boulder, CO: Westview.

Veblen, T. (2017), The theory of the leisure class. New York: Routledge (oorspronkelijke uitgave 1899).

Wexler, M.N. (2010), Financial Edgework and the Persistence of Rogue Traders. Business and Society Review, 115(1), 1-25. 
Wray, T. (2016), The Role of Leader Hubris in the Decline of RBS and Lehman Brothers. In: P. Garrard \& G. Robinson (eds.), The Intoxication of Power: Interdisciplinary Insights (pp. 229-252). Houndmills: Palgrave Macmillan.

Wright, S.L. (2010), Angel Faces, Killer Kids, and Appetites for Excess. Re-approaching moral panic (thesis). Wellington: Victoria University of Wellington. https:// pdfs.semanticscholar.org/5642/44380e4d1e729b61d43f39e256b9697661f3.pdf. 